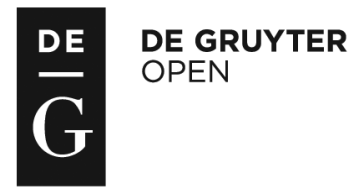

Administration, vol. 65, no. 2 (2017), pp. 15-35

doi: 10.1515/admin-2017-0013

\title{
The Irish legislative gender quota: The first election
}

\author{
Mary Brennan \\ University College Dublin \\ Fiona Buckley \\ University College Cork
}

\begin{abstract}
In 2012 legislative gender quotas were introduced as part of the Fine Gael/Labour coalition government's political reform agenda. The legislation specifies that payments to political parties 'shall be reduced by 50 per cent, unless at least 30 per cent of the candidates whose candidatures were authenticated by the qualified party at the preceding general election were women and at least 30 per cent were men'. The 30 per cent gender threshold came into effect at the 2016 general election. Research demonstrates that gender quotas work to increase women's political descriptive representation, but to do so, political parties must engage with them in 'goodwill', be 'wellintentioned' or place women in 'winnable seats'. This article examines if this was the case at the 2016 general election. Using statistics, as well as drawing from interviews with party strategists, the article assesses the impact of gender quotas on women's candidate selection and election. We conclude that parties did embrace the spirit of the gender quota law but resistance remains.
\end{abstract}

Keywords: Gender quotas, elections, informal institutional norms, political reform 


\section{Introduction}

One of the first political reform proposals announced by the Fine Gael/Labour coalition government in May 2011 were measures to address the public funding of political parties. In Ireland the public funding of political parties is administered in two ways: firstly, through money paid to political parties under the Electoral Act $1997^{1}$ and, secondly, through what is termed the parliamentary activities allowance (Standards in Public Office Commission, 2016). The former was the focus of the Electoral (Amendment) (Political Funding) Act, 2012, Part 6 of which dealt with the 'state funding of political parties and gender balance'. The Act specifies that payments to political parties 'shall be reduced by 50 per cent, unless at least 30 per cent of the candidates whose candidatures were authenticated by the qualified party at the preceding general election were women and at least 30 per cent were men'. The 30 per cent gender threshold came into effect at the 2016 general election. The threshold is due to rise to 40 per cent from 2023 onwards. Legislative gender quotas apply at general elections only.

Research demonstrates that gender quotas work, but to do so, political parties must engage with them in 'goodwill' (Matland, 2006), be 'well-intentioned' (Dahlerup, 2007) or place women in 'winnable seats' (Murray et al., 2012). Essentially, to be effective, parties must 'fully embrace' gender quotas (Buckley et al., 2014). However, writing ahead of the implementation of the gender quota law, Buckley et al. (2014, p. 479) warned that 'informal rules surrounding incumbency and localism' and male 'gendered legacies' of political parties posed challenges to the effective implementation of gender quotas in Ireland. This article examines if this was the case in 2016.

The article begins with a discussion about why measures to address the political under-representation of women were introduced for Dáil elections. Placing Ireland in a comparative context, it argues that women's political representation in Ireland remained static from the early 1990 s to 2012 , while other nation states embraced affirmative action measures which saw the proportion of women's political representation increase. Examining candidate emergence and recruitment through the 'supply and demand' analytical lens, the

1 To receive funding under the Electoral Act, 1997, as amended, a political party must achieve at least 2 per cent or more of the national first-preference vote. This funding is used for general administration, research, education and training, policy formation and branch activities. 
article identifies a number of gendered barriers to women's candidate selection, particularly demand-side factors such as informal institutional norms and requirements such as localism, incumbency and male-gendered networks. The article then assesses how political parties integrated the gender quota into their candidate recruitment and selection procedures at the 2016 general election. Using statistics, as well as drawing from interviews with party strategists, the article assesses the impact of gender quotas on women's candidate selection and election, and also assesses the extent to which informal gendered norms mollified the effectiveness of gender quotas, or were themselves mollified by the formal gender requirements. We conclude that parties did embrace the spirit of the gender quota law but resistance remains.

\section{Why a gender quota?}

When introducing the world's first legislative gender quota in a PRSTV (proportional representation by single transferable vote) electoral system in February 2012, the then Minister for the Environment, Community and Local Government, Phil Hogan, TD, described the scheme as a 'proportional response to address a significant weakness in Ireland's democratic system' (Seanad Éireann, 2012). With only 15 per cent female TDs in 2012, Dáil Éireann was ranked in eighty-ninth position in the Inter-Parliamentary Union's (IPU) global league table for women's parliamentary representation. This represented a significant decrease from a ranking of thirtyseventh position in the early 1990s (Bacik, 2009). Ireland's drop in the IPU rankings was a result of the relatively static progress in women's parliamentary representation during this period, rising from 12 per cent in 1992 to just 15 per cent in 2011 (see Table 1). However, as Ireland stood still, other nation states embraced affirmative action measures in the pursuit of better gender balance in political representation, resulting in over fifty countries progressing and surpassing it.

The UN Fourth World Conference on Women, held in Beijing in September 1995, and its resulting Beijing Declaration and Platform for Action, raised international awareness of the need to increase the representation of women in parliaments worldwide. In general, both the rights-based claim for equality of gender and the instrumental argument of the value of the female lived experience combined to make the campaign to promote gender balance in political 
Table 1: Percentage of women candidates and TDs at elections, 1992-2016

\begin{tabular}{lcc}
\hline Election & $\begin{array}{c}\text { Female candidates } \\
(\%)\end{array}$ & $\begin{array}{c}\text { Female TDs } \\
(\%)\end{array}$ \\
\hline 1992 & 18.5 & 12.0 \\
1997 & 19.8 & 12.0 \\
2002 & 18.1 & 13.3 \\
2007 & 17.4 & 13.3 \\
2011 & 15.2 & 15.1 \\
2016 & 29.6 & 22.2 \\
\hline
\end{tabular}

Source: Figures from 1992 to 2011 adapted from Buckley et al. (2015); 2016 figures are authors' calculations.

representation not only a women's issue, but also a broader requirement for a democratic government's claim of representativeness. By 2009 gender-quota measures existed in over 100 countries (Krook, 2009). Gender quotas may be adopted voluntarily by a political party or through legislation and/or constitutional provision. According to the Quota Project database, ${ }^{2}$ fifty-four countries worldwide use voluntary party quotas while seventy-seven have adopted gender quotas through the legislative and/or constitutional route.

That said, there remains a near universal under-representation of women in global politics. At the time of writing (March 2017), the IPU reports that men continue to dominate the parliaments of the world with a global supermajority of 77 per cent. Across EU member states, the average rate of women's political representation in national parliaments stands at 27 per cent. This universal inequality is argued to be evidence of an artificial repression of both the supply of and demand for women in political decision-making (Krook, 2010). The supply and demand model (Norris \& Lovenduski, 1995), or what Norris $(1997$; 2006) refers to as the softer structural elements of political recruitment, outlines that resources and motivational factors are central to understanding the under-supply of women into politics, while the gendered biases, attitudes and preferences of candidate selectorates lead to a repression in the demand for women candidates.

2 Quota Database: www.quotaproject.org [accessed 27 March 2017]. 


\section{Supply}

Embarking upon and nurturing a political career requires key resources, namely time, funds and networks, as well as motivational factors such as interest and ambition (White et al., 2015). Ireland is a progressive country, ranking sixth in the Global Gender Gap Index in 2016, but there remains a bias towards traditional gender roles (Galligan, 2010; White et al., 2015). Women continue to be the main care providers (Ferrant et al., 2014) and to earn less than men (World Economic Forum, 2016). The average gender pay gap in Ireland in 2016 was 14 per cent (European Commission, 2016). Gendered differences in pay and care commitments impact upon the availability of time and financial resources, meaning men are more likely than women to possess such capital to develop a political career and fund political campaigns.

In terms of motivational factors, White et al. (2015, p. 206) demonstrated, using European Values Survey data, a gap between men's and women's political interest in Ireland but noted 'that women are increasingly interested in politics and... gender-based differences are not so great as to hinder the ability of parties to find potential female candidates to run for office' (see Figure 1). However, the lack of women in Irish politics has curtailed role-model effects, inhibiting women's confidence and ambition to pursue a political career (Buckley et al., 2015). Compounding this is the fact that masculinity is the basis on which politics is constructed and the 'norm' against which all political activity is judged (Connolly, 2013; Duerst-Lahti \& Kelly, 1995; Harmer et al., 2016, p. 4). The potency of this male-gendered way of 'doing' politics is so strong as to be assumed as the universal norm for political activity, contributing to a notion of men as 'natural leaders' (Duerst-Lahti, 2002, 2008). Women entering politics are contrasted against the 'naturalised' male inhabitants (Puwar, 2004). Their presence is queried and behaviour scrutinised, which, in turn, contributes 'to a notion of women as out of place and unnatural in the political sphere' (Falk, 2010, p. 37; Puwar, 2004).

Socio-structural and cultural studies demonstrate that increases in the supply of female politicians usually follow growth in women's participation in the workforce, and point to specific careers or 'pipeline professions', notably legal, civil service and education, from which candidates are most likely to emerge. CSO data show that the female employment rate in Ireland stood at 55.1 per cent in 2012, up from 32.2 per cent in 1991 (Walsh, 1992, p. 1), a jump of 22.9 percentage points. However, the percentage point change in women's 


\section{Figure 1: Percentage of Irish respondents 'somewhat' or 'very interested' in politics, by sex}

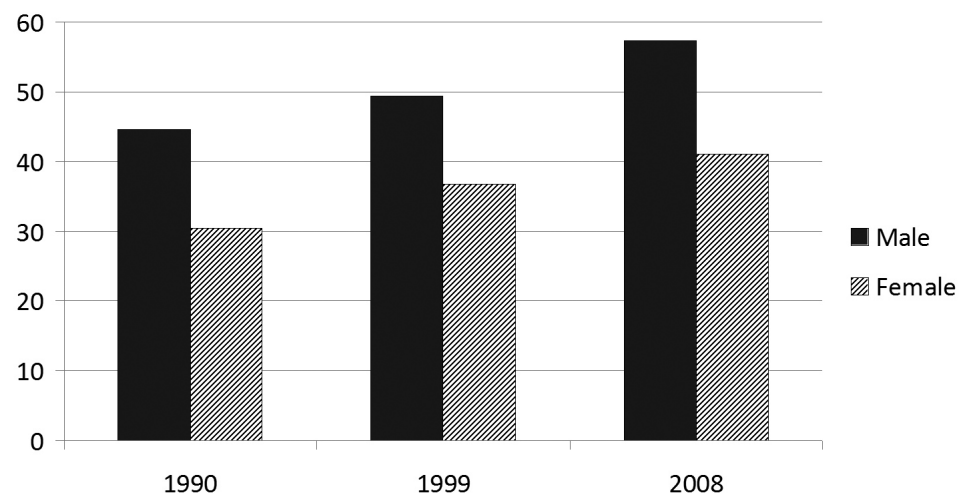

Source: White et al. (2015, p. 206).

representation in Dáil Éireann increased by a mere three points during this period. In terms of the occupational backgrounds of politicians, teaching consistently features as a prominent career among TDs, providing key political resource opportunities, including connectedness to a local area and profile-building. It is a profession that is dominated by women -84 per cent of all teachers during the academic year 2014/15 were women (Central Statistics Office, 2016). Women's workforce participation rates and their dominance of one of the key feeder professions into politics show that women with ability and qualifications are readily available within Irish society to contest politics. However, up to and including the 2011 general election, women's candidacy levels remained low. As noted, confidence, or lack thereof, impacts women's ambition and motivation to enter politics, while differential access to key political resources, such as time and money, privileges male candidate emergence and stymies women's (Culhane, 2017). But the question of demand must also be interrogated. Supply factors may curtail women's access to politics, but if political parties do not seek women candidates, then their opportunities to break onto the political scene are limited.

\section{Demand}

While it is universally agreed that PR electoral systems are more favourably disposed to the election of women, this is understood in 
comparison to plurality systems. Within the many variations of PR electoral systems, the Irish STV has been found to mediate differently with candidate selection depending on the district size (McGing, 2013), with three-seat constituencies being the least facilitating of female political aspirants, as political parties tend to stick with the tried and tested incumbent, usually a man. However, electoral systems have been found to have not alone mechanical effects but also psychological consequences for voters and parties (Duverger, 1986). ${ }^{3}$

It is argued that these psychological effects have a direct impact on how parties nominate their candidates (Blais et al., 2011; Gallagher \& Marsh, 1988). In the STV case, the impact poses a particular challenge to parties as selectors must carefully balance their ticket to maximise the efficiency of the vote (Farrell, 2011; Sinnott, 1995). Too few candidates on the ticket and the selectors risk gifting party votes to the competition; too many candidates selected and the party risks splitting the vote and losing a seat (Reidy, 2011). The maximisation of the party vote is the sole aim in this balancing act and, to this end, the location of a candidate also plays a role in the selection process. The candidates selected must represent a spread throughout the constituency; two excellent candidates from the same town or area would rarely be selected, as locality remains important for the Irish electorate (Gallagher \& Marsh, 1988). In effect, an informal geography or localism quota is implicitly implemented by all parties in Irish elections. As Culhane (2017, p. 46) highlights:

this privileging of 'the local' is widely known about and shapes political recruitment and selection in a number of ways... First, it has shaped informal candidate recruitment criteria, such that the perception of what makes an electable and therefore 'good' candidate is one who is locally recognised and known by constituents. Second, it has shaped perceptions of who should select candidates, a power which is principally attributed to the local branch members as opposed to central strategy committees.

To be local is to have a tapestry of integrated and networked links into the local community that affords name recognition and profilebuilding. Being a local councillor is one way of demonstrating, as well

${ }^{3}$ For example, a voter knows that a vote for a smaller party is a wasted vote under majoritarian electoral systems such as first-past-the-post, and therefore may not vote for that smaller party. 
as enhancing, 'localness'. However, as men dominate local councils, few women have an opportunity to harness localism skills, which are essential for candidate selection and election at the national level (Buckley et al., 2015). Therefore, localism as an informal candidate recruitment norm is highly gendered, with highly gendered outcomes (Culhane, 2017). Furthermore, while many women are networked into local community groups and organisations, their spheres of influence are limited as men dominate sites of political power, whether that is within political parties or local councils (Buckley, 2013; Buckley et al., 2014; Culhane, 2017; Galligan, 2010).

As noted, localism is also integral to candidate selection processes in Ireland, whereby the selection process involves interplay between local and national selection committees. Irish political history shows that even when the party leadership is convinced of the need to improve gender balance, this desire is often mediated by the low levels of district and party magnitudes, and the reluctance on behalf of the local level party to select 'new' candidates in favour of the 'tried and tested' incumbent. The role of incumbency is universally understood to be a barrier to the nomination of challengers, but as the majority of incumbents are men, the opportunity spaces for 'new' women candidates are limited (Gallagher \& Marsh, 1988; Norris \& Lovenduski, 1995). Certainly, for the Irish open ballot system, incumbency is a factor, as selectors consider electability as the key criterion for selection, and there is no greater evidence of electability than having already won a seat (Gallagher \& Marsh, 1988; Weeks, 2010).

Localism and incumbency are barriers for women who contest party selection conventions, but often female aspirants struggle to even get to this stage as their candidacy is not fostered. Candidate recruitment and selection can be viewed through the lens of Bjarnegård's (2013) 'homosociability' concept, whereby she argues that this process is often an outcome of interpersonal links, summed up in the old adage of 'who you know, not what you know'. In itself this practice is gendered to privilege men, as men, who disproportionally hold positions of power within political parties, tend to recruit and select other men for political office (Culhane, 2017, p. 49). Reviews of office holders in political parties consistently show that leadership positions are dominated by men (Buckley, 2013; Galligan, 2010; Galligan et al., 1999). It usually falls to the occupants of these leadership roles, notably constituency party chairpersons, to identify and approach potential candidates for selection convention. The evidence clearly 
points to a male bias in this regard. While women's party membership hovered between 30 to 40 per cent in 2011, women's party candidacy was approximately 19 per cent (Buckley \& McGing, 2011), demonstrating that women were disproportionally under-selected relative to their party membership rates. Party chairpersons speak of their attempts to recruit women candidates, only for women to refuse to let their names go forward for selection. Research on candidate recruitment and gender reveals that while men expect and are confident of receiving supports such as mentoring and political networking from the party leadership, women are less confident, as these supports are often dispensed through the informal channels of the 'old boys networks' (Butler \& Preece, 2016). Thus, they are reluctant to see their names go forward for candidate selection as they feel they will be 'on their own' in the contest for candidate selection and election, as informal male networks converge to privilege and sustain male political power (Butler \& Preece, 2016; Verge \& De la Fuente, 2014).

Prior to the adoption of gender quota legislation, there was little incentive to encourage female candidacy. Indeed, prior to the introduction of legislative gender quotas, parties, in general, did very little to balance party tickets for social or gender considerations (Buckley, 2013; Buckley \& McGing, 2011, p. 228; Weeks, 2010, p. 160). However, the economic crash of 2008 and the ensuing political reform discourse, which queried the representativeness and diversity of politics, would change all that. With the research highlighting the effects of Irish political culture and electoral system on women's candidacy, it became inevitable that an interventionist measure along the lines of a legislative quota was required if the gross inequality in the gender balance of Dáil Éireann was to be addressed.

\section{Data and methodology}

The adoption of legislative gender quotas is an attempt to redress the historical gender imbalance in Irish politics. This article assesses the impact of gender quotas on women's candidate selection and election, and the extent to which informal candidate selection norms such as incumbency, localism, and male-gendered institutional legacies mollified the effectiveness of gender quotas, or were themselves mollified by the formal gender requirement. To examine this, the article draws on statistical data and interviews with party strategists. 
It was noted earlier that for gender quotas to be effective, political parties must embrace quota requirements and engage with them in 'goodwill'. To examine the concept of party 'goodwill', we measure the likelihood that new female contenders are placed with male incumbents, the effects of district magnitude, and whether women are placed in seats with low levels of competition, i.e. a 'safe seat' or a 'safely unwinnable seat'. For this, a measure of marginality proposed by Brennan \& Elkink (2015) is employed:

$$
\mathrm{M}=\left|\frac{\mathrm{v}}{\mathrm{Q}}-\mathrm{s}\right|
$$

Here marginality is argued to be the absolute value of the votes (v) achieved by a party, divided by the quota (Q) less the number of seats (s) won by a given party in a given constituency. Here the value will be zero if a party achieves an exact quota (i.e. the exact number of seats required to win a seat), high if the party receives almost enough for a quota, and low if party preferences fall well short of the number of votes required for a quota.

The analysis makes use of a number of control variables that can be expected to impact on a party's decision to select a candidate. These include the use of the Pobal HP Deprivation Index 4 as a proxy for the socio-economic level of each constituency, and the levels of yes votes in the 2015 marriage equality referendum as a rough measure of liberal values in each district. The literature shows that variables such as district magnitude and incumbency can affect female candidate selection (McGing, 2013). Here the impact of district magnitude is controlled using the variable 'seats' while incumbency is controlled for in the logistic regression by looking only at the effects on nonincumbent candidates.

\section{Results}

\section{Incumbency and marginality}

A total of 551 candidates contested the 2016 general election - 163 women and 388 men. The number and proportion of women candidates (just under 30 per cent) were the highest to contest a general election in Ireland. Indeed, as demonstrated in Table 2, the proportion of women contesting general elections had been declining between 1997 and 2011. Thus, the effect of the quota is clear to see in

\footnotetext{
${ }^{4}$ Available at https://www.pobal.ie/Pages/New-Measures.aspx
} 
the absolute numbers and proportion of women selected to contest the 2016 general election.

The literature points to the inevitability of male incumbency as a barrier to new women entrants in electoral competition, as, due to male dominated parliaments, the majority of incumbents are men; albeit, the vast majority of candidates selected in the 2016 general election were not incumbents (see Figure 2), suggesting plenty of scope for parties to select new women candidates as opposed to new male ones. However, as demonstrated in Table 3, the effects of incumbency on the selection of newcomers varied depending on party. Incumbency ${ }^{5}$ was a much greater constraint for the Fine Gael and

Table 2: Candidate selection at general elections disaggregated by biological sex

\begin{tabular}{|c|c|c|c|c|c|}
\hline \multirow[t]{2}{*}{ Gender } & \multicolumn{5}{|c|}{ Election year (\%) } \\
\hline & 1997 & 2002 & 2007 & 2011 & 2016 \\
\hline Th & $80.37(389)$ & $8(379)$ & $82.52(387)$ & 84.78 & 70 \\
\hline Female & $19.63 \quad(95)$ & 18.32 & 17.48 & 15.22 & $29.58(163)$ \\
\hline
\end{tabular}

Source: Authors' own calculations.

Figure 2: New and incumbent candidates selected at the 2016 general election

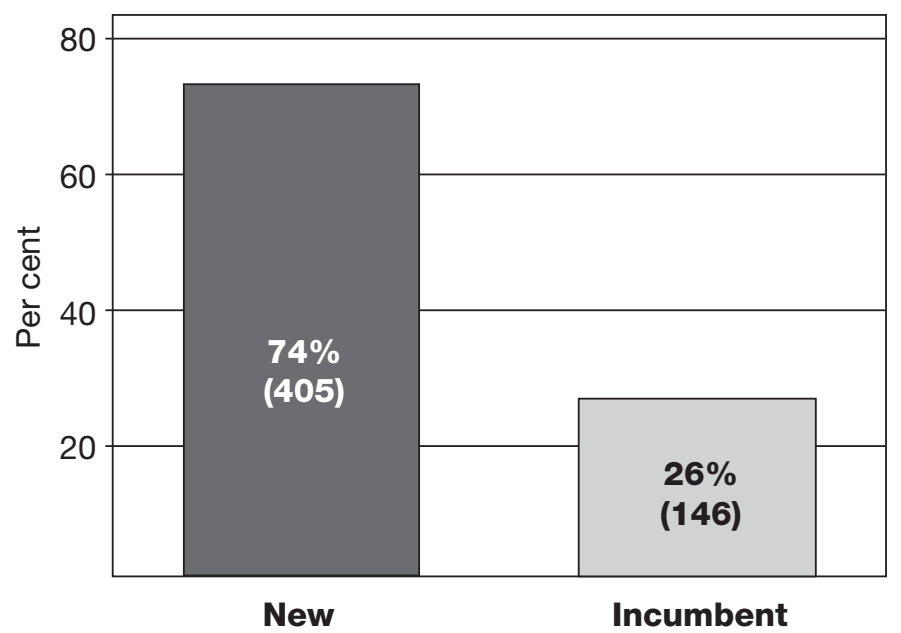

5 Incumbency covers those candidates who were outgoing TDs contesting the general election. 
Labour parties, the outgoing government parties, than it was for Fianna Fáil and Sinn Féin, the outgoing opposition.

Table 3: New and incumbent candidates selected by the four main parties in the 2016 general election

\begin{tabular}{lcccc}
\hline & $\begin{array}{c}\text { Fianna Fáil } \\
(\%)\end{array}$ & $\begin{array}{c}\text { Fine Gael } \\
(\%)\end{array}$ & $\begin{array}{c}\text { Labour } \\
(\%)\end{array}$ & $\begin{array}{c}\text { Sinn Féin } \\
(\%)\end{array}$ \\
\hline Non-incumbent & $76(53)$ & $32(28)$ & $28(10)$ & $74(37)$ \\
Incumbent & $25(18)$ & $68(61)$ & $72(26)$ & $26(13)$ \\
\hline
\end{tabular}

Source: Authors' own calculations.

Besides looking at the number and incumbency status of the candidates selected, the research shows that in the Irish case the size of the constituency matters. Table 4 shows the consistency in the distribution of selected candidates by size of district.

Table 4: Candidate selection disaggregated by district magnitude in 2016 election

\begin{tabular}{lccc}
\hline Party & $\begin{array}{c}\text { 3-seat constituency } \\
(13)\end{array}$ & $\begin{array}{c}\text { 4-seat constituency } \\
(16)\end{array}$ & $\begin{array}{c}\text { 5-seat constituency } \\
(11)\end{array}$ \\
& $(\%)$ & $(\%)$ & $(\%)$ \\
\hline Fianna Fáil & $25(18)$ & $40(28)$ & $35(25)$ \\
Fine Gael & $25(22)$ & $40(36)$ & $35(31)$ \\
Labour & $28(10)$ & $39(14)$ & $33(12)$ \\
Sinn Féin & $28(14)$ & $40(20)$ & $32(16)$ \\
\hline
\end{tabular}

Source: Authors' own calculations.

The consistency of selection patterns across the parties suggests an institutional effect of district magnitude, with all parties selecting approximately 40 per cent of their candidates in four-seat constituencies. There is a slight variation with Fianna Fáil and Fine Gael, who show a stronger tendency than Labour and Sinn Féin to select candidates in the larger seat constituencies.

Table 5 shows the selection of new, non-incumbent women candidates disaggregated by party and district magnitude. Here the variation between the parties and their selection decisions by constituency size is more apparent. When controlling for the effects of incumbency, only looking at the distribution of new non-incumbent women nominees, we see what appears to be a gendered difference in 
party behaviour. In Fianna Fáil and Fine Gael, new female aspirants are more likely to be selected in five-seat constituencies, while almost the opposite is true for Sinn Féin, where a newly selected woman is more likely to be selected in a three-seat constituency.

Table 5: Selection of non-incumbent female candidates in the 2016 general election

\begin{tabular}{lccc}
\hline Party & $\begin{array}{c}\text { 3-seat constituency } \\
(13)\end{array}$ & $\begin{array}{c}\text { 4-seat constituency } \\
(16)\end{array}$ & $\begin{array}{c}\text { 5-seat constituency } \\
(11)\end{array}$ \\
& $(\%)$ & $(\%)$ & $(\%)$ \\
\hline Fianna Fáil & $23(5)$ & $36(8)$ & $41(9)$ \\
Fine Gael & $24(4)$ & $29(5)$ & $47(8)$ \\
Labour & $33(2)$ & $34(2)$ & $33(2)$ \\
Sinn Féin & $44(7)$ & $31(5)$ & $25(4)$ \\
\hline
\end{tabular}

Source: Authors' own calculations.

New female nominees can be selected as part of a party's dual- or multi-list of candidates. Table 6 illustrates that 76 per cent of all new female nominees in Fine Gael were placed as the second or third party candidate. However, Fianna Fáil placed the majority of their female newcomers as part of single-candidate tickets.

Table 6: Selection of non-incumbent female candidates alongside male incumbents

\begin{tabular}{lccc}
\hline Party & $\begin{array}{c}\text { No male incumbent } \\
(\%)\end{array}$ & $\begin{array}{c}\text { 1 male incumbent } \\
(\%)\end{array}$ & $\begin{array}{c}2 \text { male incumbents } \\
(\%)\end{array}$ \\
\hline Fianna Fáil & $64(14)$ & $32(7)$ & $4(1)$ \\
Fine Gael & $24(4)$ & $47(8)$ & $29(5)$ \\
Labour & $83(5)$ & $17(1)$ & $0(0)$ \\
Sinn Féin & $69(11)$ & $31(5)$ & $0(0)$ \\
\hline
\end{tabular}

Source: Authors' own calculations.

To assess whether parties 'fully embraced' the gender quota requirement, we analyse how parties react to variation in seat marginality and to party male incumbency in their selection of new contenders. Following Brennan \& Elkink (2015), we argue that a party can abide by quota rules and still maintain a selectorate bias. If a negative selectorate bias is in operation within a party, we hypothesise that political parties have a tendency to select new women candidates in constituencies where they are safely accommodated, i.e. in districts 


\section{Table 7: Logistic regressions explaining the gender of non-incumbent candidates}

\begin{tabular}{lrrrrr}
\hline \multicolumn{6}{c}{ Dependent variable } \\
& Fianna & \multicolumn{1}{c}{ Fine } & Labour & Sinn & Green \\
& Fáil (1) & Gael (2) & (3) & Féin (4) & Party (5) \\
\hline Marginality & $-1.009(1.02)$ & $-0.360(0.59)$ & 223.543 & $0.492(0.61)$ & $4.000(0.34)$ \\
Male incumbents $1.137(0.59)$ & $0.011(2.93)$ & & $0.696(1.66)$ & \\
Constant & $-1.670(0.63)$ & $-2.089(1.05)$ & 168.494 & $0.320(0.63)$ & $0.139(0.72)$ \\
Observations & 53 & 28 & 9 & 37 & 39 \\
Log likelihood & -37.354 & -29.547 & -4.334 & -16.794 & -13.874 \\
\hline
\end{tabular}

Note: Controls included but not displayed.

Source: Authors' own calculations.

with low marginality, 'a safe seat' or a district where the party support is considered to be so low as to be regarded as a 'safely unwinnable seat'.

A logistic regression to test the effect of marginality and incumbency on party selection behaviour is presented in Table 7. Our main interest is in examining the selectorate bias hypothesis - that is, if marginality and party male incumbency have an effect on party selection behaviour. In short, the results show there is no evidence that either marginality or male incumbency impact party selection behaviour. That is not to say that all parties' selection behaviour was impartial. Indeed, the direction of the marginality coefficient for both Fianna Fáil and Fine Gael was negative, implying that the higher the marginality of a constituency for both of these parties, the less likely they were to select a non-incumbent female. This was not the case for either Sinn Féin or the Green Party. ${ }^{6}$ The relationship with incumbency, on the other hand, was positive for all parties, implying that non-incumbent women candidates were more likely to be selected in constituencies with a male incumbent. However, the results were not statistically significant. It should also be noted that the numbers involved for each party are very low; for example, there is no incumbency measure reported for the Greens as the party had no incumbents going into the election.

${ }^{6}$ The marginality coefficient for the Labour Party has no useful interpretation due to the collapse of the Labour vote in the 2016 election. 
It could also be argued that the lack of significant results indicates minimal evidence of selectorate bias by political parties as a reaction to the electoral gender quota. Overall, there was a positive effect on both the selection and election of women in both absolute and relative terms, indicating that the parties did indeed embrace the quota law, but there are indications that this engagement may be more the result of willpower than goodwill, as incidents of institutional sexism and male bias were evident in the candidate selection process.

\section{Gender quotas, localism and male-gendered institutional legacies}

Candidate selection conventions always have the potential to expose tensions between party headquarters (HQ) and constituency-level parties. As one party strategist interviewed for this project mused, party HQs tend to be more prudent in their approach to candidate selection, in contrast to the more ambitious aims of the constituency party. Areas of contention include the number of candidates to be selected, their geographical location within the constituency, the extent of candidates' localism credentials, as well as candidates' party apprenticeships. Procedural matters also result in tensions as HQs are accused of interfering in the democratic right of the constituency party to choose its preferred candidates. In 2016 the formal gender quota was layered onto these informal selection requirements and integrated into selection procedures.

A total of 155 selection conventions took place across the four main political parties of Fine Gael, Fianna Fáil, Sinn Féin and Labour. Of these, fifty-four were contested. A total of twelve gender directives were issued by party HQs - six by Fianna Fáil, five by Fine Gael and one by Sinn Féin. All bar three were applied on dual-candidate tickets, i.e. where party selectors were directed to select one woman and one man to contest the general election. The three single-candidate, woman-only directives were issued by Fianna Fáil in Dublin Central and Dublin South Central and for the Longford County selection convention in the Longford-Westmeath constituency. In addition to the gender directives, parties identified constituencies where women's candidacy was to be encouraged and nurtured.

The querying of women candidates' meritocracy was not an uncommon narrative throughout the candidate selection and general election period. It was a question rarely asked of male politicians. As research from Buckley et al. (2016, p. 192) demonstrates, women 'were not electoral novices' (see Table 8). Across the four main political parties, just under 72 per cent of all women candidates had previous experience of holding political office. 


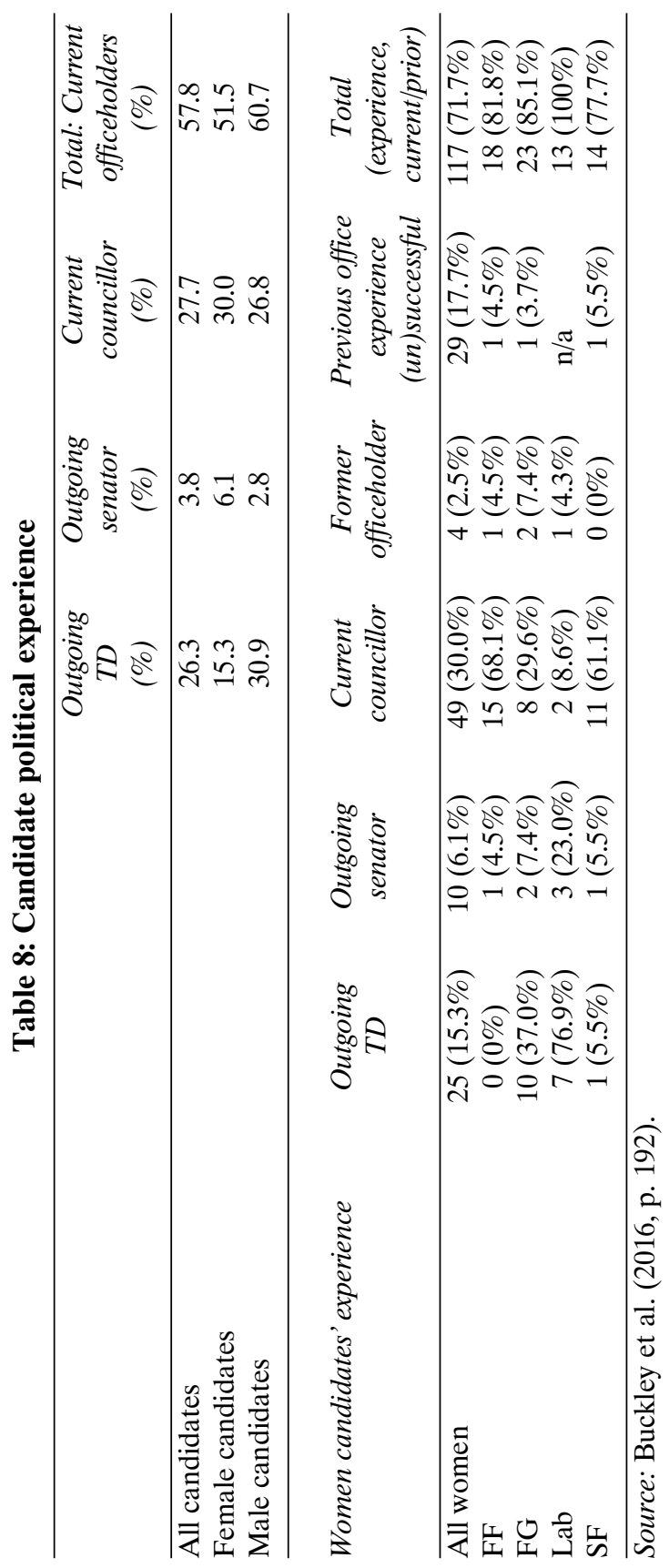


To ensure that the $30 / 70$ gender balance was maintained in candidate selection, some party strategists admitted that once they had achieved the quota, they did not select or add additional candidates, inferring that any additional candidate would be a man. This betrays an implicit male bias. One strategist spoke about recruiting women candidates for largely 'sweeper' roles. However, it is clear that women candidates did not see themselves as making up the numbers, and engaged in strong election campaigns. In cases where party resources permitted, women candidates negotiated generous election resource packages for themselves from party HQs in the form of posters, advertisements, capacity-building and campaign teams. This was done to overcome concerns that locally allocated resources would not be distributed equally among male and female candidates.

Another dominant narrative was that gender quotas were undemocratic - in particular, a sense that gender directives removed the right from constituency party members to select the candidate, usually male, who they wanted to contest the general election. As noted, accusations of this nature are par for the course at selection conventions. However, the advent of gender quotas saw a more nuanced and gendered narrative emerge, that of the displaced male candidate. Given that 70 per cent of candidates were male, it was easy to refute such denunciations. Moreover, the strong vote-getting performances of female candidates vindicated their selection. Yet, the tensions that arose surrounding the selection of some female candidates exposed a form of local democracy infused with malegendered norms of candidate preference.

Overall, the legislative gender quota incentivised political parties to select women candidates, engendered cultural change, encouraged political parties to pursue and foster women's candidacy, and was a powerful mechanism in confronting challenges from quota opponents. In 2016 political parties simply could not afford to overlook women. Thus, it can be assessed that gender quotas mollified informal institutional and gendered norms.

Party strategists were in agreement that the "unintended consequences' of gender quotas were all positive, resulting in the identification of quality women candidates who proved their electability through their election to the thirty-second Dáil, or their potential through strong vote-getting performances. These women will likely contest future local and Dáil elections. 


\section{Discussion and conclusion}

Overall, the study finds no significant evidence of selectorate bias by political parties as a reaction to the electoral quota. There was a positive effect on both the selection and election of women, with women's candidacy levels increasing by 90 per cent since the 2011 general election and the number of women TDs increasing by 40 per cent, up from 25 in 2011 to 35 in 2016 . Thus, we conclude that the political parties did embrace the quota and that the integration of the formal gender quota in candidate selection processes somewhat mollified localism and informal, male-gendered institutional norms.

However, resistance to gender quotas endures. There is an ongoing constitutional challenge to gender quotas working its way through the courts system. As noted, the quota threshold is to rise to 40 per cent from 2023 onwards, and party strategists have already begun to air concerns about achieving the increased quota. Such concerns have the potential to become a self-fulfilling prophecy if not challenged. The reality is that in achieving the 30 per cent quota, many parties increased their proportion of female candidacy by more than the maximum 10 percentage point jump required to meet the higher gender threshold, thus proving that they can engender change in their candidate recruitment processes. Expressing concerns about achieving the higher gender quota may feed into a negative narrative around the gender quota and a dilution of its effectiveness. Such instances of resistance and hesitancy are not unusual. In a cross-national study, Krook (2016) has highlighted the many ways in which gender quotas have been weakened once the scheme has been introduced. She has identified evidence of parties using minimal interpretations, engineering female electoral losses, forcing women to stand aside in pre-electoral pacts, or recruiting wives and daughters of existing male incumbents, thereby reproducing existing institutions rather than empowering new norms.

The international experience is a forewarning for Ireland. Institutions are adaptable, which can result in transformations but can also produce resistance. Gender quotas can, and in the case of Ireland, do affect change. However, political parties and their candidate recruitment practices must be closely monitored. To not do so risks a reproduction of male-gendered norms, undermining the effectiveness of gender quotas which was achieved in 2016. 


\section{Acknowledgements}

The authors would like to acknowledge the support of the Irish Research Council's New Foundations funding scheme in facilitating this research.

\section{Bibliography}

Bacik, I. (2009). Women's participation in politics, second report [Joint Committee on Justice, Equality, Defence and Women's Rights]. Dublin: Houses of the Oireachtas.

Bjarnegård, E. (2013). Gender, informal institutions and political recruitment: Explaining male dominance in parliamentary representation. London: Palgrave Macmillan.

Blais, A., Lachat, R., Hino, A., \& Doray-Demers, P. (2011). The mechanical and psychological effects of electoral systems: A quasi-experimental study. Comparative Political Studies, 44 (12), 1,599-621.

Brennan, M., \& Elkink, J. A. (2015, October 16-18). Progress or tokenism? Female candidate selection by parties in local elections under an informal quota regime. Paper prepared for the Political Science Association of Ireland Annual Conference, Cork.

Buckley, F. (2013). Women and politics in Ireland: The road to sex quotas. Irish Political Studies, 28 (3), 341-59.

Buckley, F., Galligan, Y., \& McGing, C. (2016). Women and the election: Assessing the impact of gender quotas. In M. Gallagher \& M. Marsh (Eds), How Ireland voted 2016: The election that nobody won (pp. 185-205). London: Palgrave.

Buckley, F., Mariani, M., McGing, C., \& White, T. (2015). Is local office a springboard for women to Dáil Éireann? Journal of Women, Politics \& Policy, 36 (3), 311-35.

Buckley, F., Mariani, M., \& White, T. J. (2014). Will legislative gender quotas increase female representation in Ireland? A feminist institutionalism analysis. Representation, 50 (4), 471-84.

Buckley, F., \& McGing, C. (2011). Women and the election. In M. Gallagher \& M. Marsh, How Ireland voted 2011: The full story of Ireland's earthquake election (pp. 222-39). London: Palgrave Macmillan.

Butler, D. M., \& Preece, J. R. (2016). Recruitment and perceptions of gender bias in party leader support. Political Research Quarterly, 69 (4), 842-51.

Central Statistics Office. (2016). Life in 1916 Ireland: Stories from statistics Education. Retrieved from http://www.cso.ie/en/releasesand publications/ ep/p-1916/1916irl/society/education/ [27 March 2017].

Connolly, E. (2013). Parliaments as gendered institutions: The Irish Oireachtas. Irish Political Studies, 28 (3), 360-79.

Culhane, L. (2017). Local heroes and 'cute hoors': Informal institutions, male over-representation and candidate selection in the Republic of Ireland. In 
G. Waylen, Gender and informal institutions (pp. 45-66). London: Rowman and Littlefield International.

Dahlerup, D. (2007). Electoral gender quotas: Between equality of opportunity and equality of result. Representation, 43 (2), 73-92.

Duerst-Lahti, G. (2002). Governing institutions, ideologies, and gender: Toward the possibility of equal political representation. Sex Roles, 47 (7-8), $371-88$.

Duerst-Lahti, G. (2008). Gender ideology: Masculinism and feminalism. Politics, Gender, and Concepts: Theory and Methodology, 159-192.

Duerst-Lahti, G., \& Kelly, R. M. (1995). Gender power, leadership, and governance. Michigan: University of Michigan Press.

Duverger, M. (1986). Duverger's law: Forty years later. In B. Grofman A. \& Lijphart (Eds), Electoral laws and their political consequences (pp. 69-84). New York: Algora Publishing.

European Commission. (2016). The gender pay gap in Ireland. Retrieved from http://ec.europa.eu/justice/gender-equality/files/gender_pay_gap/2016/ gpg_country_factsheet_ie_2016_en.pdf [27 March 2017].

Falk, E. (2010). Women for president: Media bias in nine campaigns. Illinois: University of Illinois Press.

Farrell, D. M. (2011). Electoral systems: A comparative introduction. London: Palgrave Macmillan.

Ferrant, G., Pesando, L. M., \& Nowacka, K. (2014). Unpaid care work: The missing link in the analysis of gender gaps in labour outcomes. Retrieved from https://www.oecd.org/dev/development-gender/Unpaid_care_work.pdf [10 December 2016].

Gallagher, M., \& Marsh, M. (1988). Candidate selection in comparative perspective: The secret garden of politics. Newbury Park, Calif: SAGE Publications Ltd.

Galligan, Y. (2010). Women in politics. In J. Coakley \& M. Gallagher (Eds), Politics in the Republic of Ireland (5th ed., pp. 263-91). London: Routledge in association with PSAI Press.

Galligan, Y., Ward, E., \& Wilford, R. (1999). Contesting politics: Women in Ireland, North and South. Boulder, CO: Westview Press and PSAI Press.

Harmer, E., Savigny, H., \& Ward, O. (2016). 'Are you tough enough?' Performing gender in the UK leadership debates 2015. Media, Culture \& Society. Advance online publication. doi: 0163443716682074

Krook, M. L. (2009). Quotas for women in politics: Gender and candidate selection reform worldwide. Cary, NC: Oxford University Press.

Krook, M. L. (2010). Why are fewer women than men elected? Gender and the dynamics of candidate selection. Political Studies Review, 8 (2), 155-68. Krook, M. L. (2016). Contesting gender quotas: Dynamics of resistance. Politics, Groups, and Identities, 4 (2), 268-83.

Matland, R. E. (2006). Electoral quotas: Frequency and effectiveness. In D. Dahlerup (Ed), Women, quotas and politics. New York: Routledge. 
McGing, C. (2013). The single transferable vote and women's representation in Ireland. Irish Political Studies, 28 (3), 322-40.

Murray, R., Krook, M. L., \& Opello, K. A. (2012). Why are gender quotas adopted? Party pragmatism and parity in France. Political Research Quarterly, 65 (3), 529-43.

Norris, P. (1997). Passages to power: Legislative recruitment in advanced democracies. Cambridge: Cambridge University Press.

Norris, P. (2006). Recruitment. In R. Katz \& P. Mair (Eds), Handbook of party politics. London: SAGE Publications Ltd.

Norris, P., \& Lovenduski, J. (1995). Political recruitment: Gender, race and class in the British Parliament. Cambridge: Cambridge University Press.

Puwar, N. (2004). Thinking about making a difference. The British Journal of Politics and International Relations, 6 (1), 65-80.

Reidy, T. (2011). Candidate selection. In M. Gallagher \& M. Marsh, How Ireland voted 2011: The full story of Ireland's earthquake election. London: Palgrave Macmillan.

Seanad Éireann. (2012). Electoral (Amendment)(Political Funding) Bill 2011: Second stage. 2 February. Seanad Debates, 213 (3).

Sinnott, R. (1995). Irish voters decide: Voting behaviour in elections and referendums since 1918. Cambridge: Cambridge University Press.

Standards in Public Office Commission. (2016). Guidelines for the general election to the 32nd Dáil to be held on 26 February 2016. Retrieved from http://www.sipo.gov.ie [6 April 2017].

Verge, T., \& De la Fuente, M. (2014). Playing with different cards: Party politics, gender quotas and women's empowerment. International Political Science Review, 35 (1), 67-79.

Walsh, B. M. (1992). Labour force participation and the feminising of the labour force. Retrieved from http://researchrepository.ucd.ie/handle/10197/1685 [5 April 2017].

Weeks, L. (2010). Parties and the party system. Politics in the Republic of Ireland, 5, 137-67.

White, T. J., Mariani, M., Buckley, F., \& McGing, C. (2015). Women's political role in old and new Ireland: From marginalization to gender quotas. In S. Crosson \& W. Huber (Eds), Towards 2016: 1916 and Irish literature, culture \& society. Trier: Wissenschaftlicher Verlag Trier.

World Economic Forum. (2016). The global gender gap report 2016. Retrieved from https:/www.weforum.org/reports/the-global-gender-gap-report-2016 [5 April 2017]. 